\title{
ibriez
}

Volume : 3

Nomor : 2

Tahun : 2018

\section{Mengenal Pluralisme Disintegratif Menuju Pluralisme Integratif Masyarakat Beda Agama Di Kelurahan Karang, Kecamatan Slogohimo, Kabupaten Wonogiri}

\author{
Ahmad Sakirin \\ IAIN Ponorogo \\ Surel : sakirin@iainponorogo.ac.id
}

\begin{abstract}
Abstrak
Bangsa Indonesia adalah bangas yang plural. Hal ini ditunjukkan dari berbagai macam suku, agama etnis serta beragam budaya yang menjadi simbol ciri khas bangsa kita. Kepluralan ini hendaknya mampu kita sikapi dan eksplor menjadi sebuh komoditi kekayaan, dimana secara subtantif keberadaannya ini bisa menjadikan nilai-nilai investasi yang patut diperhitungkan sebagai asset non fisik untuk bisa dilestaraikan sehingga menjadi modal devisa pariwisata yang luar biasa. Salah satu alasan yang mendasar adalah terbinanya kelestaraian berbagai macam budaya atau simbol-simbol budaya tetap lestari hingga sekarang, tanpa adanya konflik yang berkepanjangan yang kerap kali menjadi penyebab persoalan hancurnya (disintegratif) suatu peradaban.

Model-model pluralitas yang kerap kali menjadi momok hancur/lunturnya bahkan hilangnya suatu peradaban menjadi biang keladi sebagai tuduhan klasik penyebab disintegratif sering kali di patahkan dan tidak bisa dibuktikan dimasyarakat kita, terutama masyarakat Karang, Slogohimo, Wonogiri. Peran serta warga serta para tokoh masyarakat menjadi kunci bagaiman terbina ukhuwah dalam kehidupan keberagaman agama, budaya, serta sikap teleransi tinggi yang lebih mengedepankan keharmonisan hidup. Sikap atau nilai-nilai ini terlebur dalam kebiasaan sehari-hari masyarakat dengan terus menjalin rasa tali silaturrahmi demi menjaga setiap perbedaan yang komplek, baik perbedaan agama, budaya, sikap, doktrin-doktrin agama (aliran konsep doktrin NU dan Muhammadiyah atau doktrin/ajaran Protestan dan Katolik) serta ajaran lain yang masih hidup dalam masyarakat disana.

Corak dan model kehidupan yang penuh kebhinekaan ini yang tetap menjaga nilai-nilai luhur ini sangat jarang kita temui dalam suatu sistem masyarakat lain disuatu bangsa. Hal ini tentu pantas mendapatkan nilai apresiasi yang tinggi, karena tidak semudah itu melihat kenyataan suatu masyarakat yang multi kultur tanpa di temui adanya percikan atau gesekan berarti. Sepintas mata memandang, masyarakat Karang tak jauh beda dengan masyarakat lainnya yang ada di sekitarnya. Dari segi kehidupan, mata pencaharian, ekonomi, potensi-potensi lain nampak tak berarti bahkan tak layak mempunyai nilai lebih, karna itulah, dengan penulisan ini akan memberikan perspektik informasi lain yang nantinya bisa menjadi rujukan (metode) membangun suatu masyarakat sipil bangsa ini yang penuh kepluraris dengan tetap mengedepankan sikap keharmonis yang lentur.

Konsep edukasi seperti diatas tentu akan menjadi ikon dalam mengedepankan upaya penyelesain konflik/isu yang berkepanjangan. Isu-isu publik yang sering kali menawarkan perpecahan bukan hal yang selama ini tidak dapat diselesaikan dengan jalan damai. Akan tetapi, kita sepakat sebut bahwa ajaran atau konsep diatas yang lebih menekankan sikap pluralisme
\end{abstract}


disintegratif (perpecahan) bisa membuahkan hasil dalam wacana sikap plurarisme integratif yaitu penyatuan dan keutuhan kehidupan sosial dengan tetap mengedepan sikap toleransi kemajemukan.

\section{Kata Kunci: Pluralisme, Simbol, Disintegratif/Integratif, Harmonis, Kebhikekaan, Edukasi}

\section{PENDAHULUAN}

Pandangan pluralisme merupakan fakta bagian dari kehidupan yang tidak mungkin dihindari.Manusia hidup dalam pluralisme dan merupakan bagian dari pluralisme itu sendiri, baik secara pasif maupun aktif, tak terkecuali dalam hal keagamaan. ${ }^{1} \quad$ Pluralisme dalam keagamaan sebenarnya dapat menjadi kekayaan luar biasa bagi bangsa yang layak untuk dipertahankan, namun di sisi lain jika tidak dipahami secara baik dan arif oleh pemeluk agama, pluralisme justru menjadi tumbal dalam konflik yang terjadi di tengah-tengah masyarakat baik konflik intern maupun antar umat beragama, yang akhirnya menimbulkan konflik sosial sehingga dengan banyaknya keberagaman justru menimbulkan pluralisme yang disintegratif.

Masih melekat dalam ingatan kita beberapa daerah di Indonesia termasuk yang pernah mengalami beberapa kali peristiwa kekerasan dan kerusuhan yang disebabkan masalah perbedaan agama. ${ }^{2}$ Dalam banyak kasus perbedaan atau pluralitas sering melahirkan konflik sosial, bahkan berkepanjangan yang sulit dimediasi karena ideologi agama tertentu menyatu dengan keyakinan beragama. Konflik demikian juga bisa dilihat di

\footnotetext{
${ }^{1}$ Harold Coward, Pluralisme dan Tantangan AgamaAgama (Yogyakarta: Kanisius, 1989), 5.

2 Erwin Kusumastuti, "Strategi dan Praktik Kerukunan Beragama dalam Perspektif Pendidikan Multikultural" (UIN Sunan Kalijaga, 2016), 1-2.
}

beberapa daerah di Jawa, Madura dan di Luar Jawa, Tragedi Sampit di Kalimantan (antara Suku Madura dengan Suku Dayak). Banyak faktor yang memicu terjadinya berbagai permasalahan plural yang disintegratif tersebut, bisa faktor agama juga bisa faktor selain agama. Faktor agama yang paling dominan sehingga menyebabkan terjadinya disintegratif dalam masalah agama adalah pemaham keagamaan yang dipahami secara sempit dan kaku. ${ }^{3}$ Meminjam pendapatnya Joachim Wach seorang sarjana ahli sosiologi agama yang berpendapat bahwa ketika agama hadir dalam suatu masyarakat dan disinteragtif tidak dapat dielakkan hal ini disebabkan karena agama hadir dengan seperangkat ritual dan sistem kepercayaan yang lama-lama melahirkan suatu komunitas tersendiri yang berbeda dari komunitas pemeluk agama lain. Rasa perbedaan tadi kian intensif ketika para pemeluk suatu agama telah sampai pada sikap dan keyakinan bahwa satu-satunya agama yang benar adalah agama yang dipeluknya. Sedangkan yang lain salah dan kalau perlu dimusuhi. ${ }^{4}$ Padahal walaupun berbagai fakta di lapangan bahwa dengan adanya pluralisme seringkali menimbulkan disintegrasi, tentunya hal tersebut patut dipertanyakan, apalagi jika pemicu

\footnotetext{
3 Priyono Priyono, "Pluralisme Agama dan Konflik," Analisa Journal of Social Science and Religion 15, no. 02 (2008): 134.

${ }^{4}$ Joachim Wach, The Sociology of Religion (Chicago: University of Chicago Press, 1971), 35.
} 
disintegrasinya adalah faktor agama. Tanpa maksud menganggap semua agama adalah sama. Tetapi bukankah agama telah mengajarkan integrasi.Persaudaraan atas dasar iman, kebangsaan dan kemanusiaan, agama juga mengajarkan kedamaian dan kerukunan diantara manusia dan makhluk, juga mengajarkan budi pekerti yang luhur, hidup tertib dan kepatuhan terhadap aturan yang berlaku dalam masyarakat. ${ }^{5}$

Keberadaan masyarakat di Kelurahan Karang, Kecamatan Slogohimo, Kabupaten Wonogiri (selanjutnya disingkat: Karang, Slogohimo, Wonogiri), adalah masyarakat dengan tingkat keberagaman agama dan aliran kepercayaan yang sangat pluralistik. Untuk pemeluk agama terbagi atas umat Islam, Hindhu, Kristen, dan Katholik, sedangkan untuk aliran kepercayaan terdapat aliran kepercayaan Sapto Dharmo.Agama Islam sendiri terdapat beberapa organisasi mulai dari NU (Nahdlatul Ulama), Muhamadiyah, LDII (Lembaga Dakwah Islam Indonesia), dan MTA (Majelis Tafsir Alquran). Agama Kristen ada yang Kristen Protestan, Kristen Khatolik, dan Kristen Gereja Jawa. ${ }^{6}$ Adapun agama Budha yang ada di Karang Slogohimo kebetulan Budha Theravada yang tergabung dalam Vihara Dhamasasana.

Adapula sebuah kegiatan rutin (selapan sekali) dilaksanakan di desa ini bernama Pangestu, merupakan kegiatan "Pendidikan Jiwa" yang diikuti oleh lintas

\footnotetext{
${ }^{5}$ Muntaha Azhari dan Abdul Mun'im Saleh, Islam Indonesia menatap masa depan (Jakarta: Perhimpunan Pengembangan Pesantren dan Masyarakat, 1989), 81-96.
}

agama. Dengan berbagai ragam pluralitas pada agama dan masyarakat di Desa Karang, Slogohimo, Wonogiri ini justru dengan keberagaman menunjukkan adanya indikasi pluralisme yang integratif.Indikasi tersebut terlihat adanya penggunaan simbol-simbol budaya dan masyarakat memaknai berbagai simbol tersebut dalam interaksi sosial.Hal ini sekaligus menjadikan bantahan tidak selamanya bahwa pluralisme itu selalu berkonotasi dengan disintegrasi. Fenomena ini menjadi menarik untuk diketahui lebih dalam tentang banagaimana Mengenal Pluralisme Disintegratif menjadi Pluralisme Integratif Masyarakat Beda Agama sebagaimana yang terjadi di Kelurahan Karang, Slogohimo Wonogiri. Sebab, tidak selamanya potensi disintegrasi karena perbedaan pandangan apalagi di bidang agama melahirkan konflik sosial masyarakat. Berbicara tentang Kelurahan Karang, sampai hari ini belum banyak peneliti yang mengeksplor secara mendalam tentang keberadaan Kelurahan Karang Slogohimo Wonogiri, baik dari sisi kehidupan ekonomi, sosial maupun budayanya. Hal ini dapat dimaklumi mungkin karena daerah Kelurahan Karang termasuk wilayah yang terbilang jauh dari pusat kota Kabupaten Wonogiri, terlebih dari pusat Ibu Kota Provinsi Jawa Tengah yakni Semarang. Dan juga masih jarangnya akomodasi transportasi umum menuju ke lokasi. Padahal pemandangan alamnya sangat memukau dan begitu

\footnotetext{
${ }^{6}$ Analisis Interaksionisme Simbolik Masyarakat Beda Agama Kelurahan, Karang, Slogohimo, Wonogiri (Ponorogo: IAIN Ponorogo, 2017).
} 
indah. Hamparan sawah, sungai dan tiupan angin begitu tentram dan nyaman untuk dinikmati keindahannya.

Penduduk kelurahan Karang mayoritas berprofesi sebagai petani dan buruh petani, karena wilayahnya yang diisi dengan dataran tinggi sehingga hamparan sawah sangat mendominasi di daerah ini. Tercatat pada tahun 2012, ada sebanyak 485 keluarga yang tidak memiliki tanah pertanian, dan 3 kali lipat lebih darinya jumlah keluarga yang memiliki tanah pertanian, yakni sejumlah 1.365 keluarga. Luas tanah untuk padi sawah mencapai 145 Ha dengan hasil panen 2.175 Ton/ha.Selain komoditi tanaman pangan padi, penduduk juga menanam jagung dan ubi kayu.

Kelurahan Karang merupakan salah satu dari 15 desa dan dua kelurahan yang ada di Kecamatan Slogohimo Kabupaten Wonogiri. Ditinjau dari sisi astironomi, Kelurahan Karang terlihat berada pada posisi 7o 47' 54.53'-7o 47' 57.71" Bujur Timur (BT) dan 111 9' 55.06"-111' 10' 27.16" Lintang Selatan (LS). Sedangkan untuk batas wilayah Kelurahan Karang dengan wilayah lainnya adalah: batas wilayah utara; Desa Sokoboyo Kecamatan Slogohimo. Batas wilayah selatan: Desa Gunan Kecamatan Slogohimo. Batas wilayah timur; Desa Randusari Kecamatan Slogohimo.Batas wilayah barat; Desa Slogoretno Kecamatan Jatipurno. ${ }^{7}$

Kelurahan Karang secara wilayah memiliki total luas $314,86 \mathrm{ha} / \mathrm{m}^{2}$. Luas

\footnotetext{
${ }^{7}$ Balai Pemberdayaan Masyarakat Desa, "Daftar Isian Potensi Desa dan Kelurahan, lampiran II Permendagri No. 122007 Pedoman Penyusunan dan
}

wilayah tersebut terdiri dari 297,91 ha/m² luas pemukiman dan sisanya terbagi menjadi luas persawahan, perkebunan, kuburan pekarangan dan perkantoran kelurahan Karang. ${ }^{8}$ Selain wilayah pemukiman, luas persawahan dan perkebunan menempati wilayah terluas kedua yakni seluas 19,8 ha/m². Terdapat sedikitnya 10 sumber mata air dan 4 buah sungai. Kelurahan Karang berada pada daerah pegunungan atau dataran tinggi dimana terletak pada 700-900 $\mathrm{m}$ di permukaan laut (mdl). Sedangkan suhu rata-rata harian mencapai $33^{\circ} \mathrm{C}$. Volume hujan rata-rata $760 \mathrm{~m}$ per bulan. Meskipun volume hujan termasuk tinggi, namun saat tiba musim kemarau banyak wilayah yang gersang dan tandus.

Tercatat memiliki kepadatan penduduk sebanyak 3.905 orang, yang terbagi 1.942 jumlah laki-laki dan 1.960 perempuan. Dan terkumpul dalam 1.181 Kepala Keluarga (KK) dengan kepadatan penduduk rata-rata 200 per $\mathrm{km}$. Mata pencarian penduduk banyak sebagai petani dan buruh tani yakni sebanyak 2173 orang. Sedangkan tingkat pendidikan penduduknya mayoritas tamat SMP/sederajat, meskipun begitu sudah ada pula yang mengenyam pendidikan sampai lulus pendidikan tinggi S2. ${ }^{9}$

Adapun persentase jumlah penduduk menurut agama pada tahun 2012 yaitu: Islam sebanyak 3.167 pemeluk, Kristen sebanyak 37 pemeluk, Khatolik sebanyak 23 pemeluk, Budha

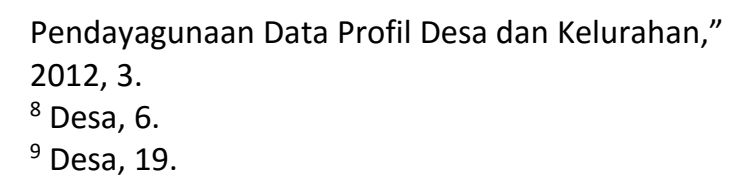

\footnotetext{
${ }^{9}$ Desa, 19.
} 
sebanyak 382 pemeluk dan Kepercayaan Kepada Tuhan Yang Maha Esa sebanyak 96 pemeluk. Sedangkan jumlah rumah ibadah menurut agama-agama yang ada di Kelurahan Karang pada tahun 2017 adalah Masjid berjumlah 4 buah; 6 Mushalla/Langgar; 1 Gereja Kristen dan 1 Wihara.

Bangsa Indonesia adalah termasuk bangsa yang paling tinggi tingkat keberagamannya di dunia.Di Negara yang terdiri dari beribu-ribu gugusan pulau dan hamparan laut terdapat lebih dari 250 juta jiwa yang menghuni ibu pertiwi.Tidak kurang dari 300 etnis dengan kekhasan identitas kulturalnya masing-masing dan masih ada ratusan bahasa yang digunakan sebagai alat komunikasi penduduknya. ${ }^{10}$ Kendatipun demikian kehidupan masyarakat tetap berjalan dengan apa adanya selama bertahun-tahun. Masyarakat yang hidup dengan suku yang berbeda, adat, bahasa dan agama dapat hidup rukun.Meskipun tidak dapat dipungkiri tetap ada gesekan dan konflik yang terjadi ditengah-tengahnya, namun semua gesekan dan konflik itu masih dalam tahap terkendali. Semua itu merupakan bagian dari dinamika masyarakat.

Kemajemukan bangsa Indonesia, juga disebabkan hampir semua agamaagama besar yang ada, yakni Islam, Kristen Protestan, Budha, Hindu, Katholik dan Konghucu ikut mewarnai keberagaman di

\footnotetext{
${ }^{10}$ Umi Sumbulah dan Nurjanah Nurjanah, Pluralisme agama: Makna dan lokalitas pola kerukunan antarumat beragama (Malang: UIN Maliki Press, 2013), 107.

${ }^{11}$ Lely Nisvilyah, "Toleransi Antarumat Beragama Dalam Memperkokoh Persatuan Dan Kesatuan Bangsa (Studi Kasus Umat Islam Dan Kristen Dusun
}

negeri ini. ${ }^{11}$ Di sisi lain, adanya peran berbagai macam bahasa, adat dan budaya ditengah-tengah bentuk negara kepulauan, juga menyebabkan penghayatan, pengamalan dan pemahaman keagamaan bangsa ini unik jika dibandingkan dengan bangsa-bangsa, inilah yang disebut sebagai "Miniatur Indonesia". Bagi masyarakat disana, perbedaan sama sekali tidak menjadikan halangan untuk saling menumbuhkan sikap kepedulian sosial sesama warga. Dan hal ini sudah berlangsung selama bertahun-tahun di lingkungan warga setempat.

Harmoni dan toleransi, kata itu begitu merekat bagi masyarakat penduduk kelurahan Karang. Membincangkan toleransi ${ }^{12}$ di daerah ini berarti toleransi yang sangat dijunjung tinggi warganya.Karang adalah daerah baru yang selalu unik dan menarik untuk didiskusikan tentang keberagamannya, keharmonisan dan toleransi agamanya.

\section{Makna Pluralisme Dalam Kerukunan Umat Beragama}

Agama hadir di bumi sebagai petunjuk bagi penciptaan manusia yang penuh keteraturan dan keharmonisan.Namun, kehadiran agama tidak tampak dalam wajah yang seragam layaknya ketidakseragaman manusia itu sendiri. Hal ini, berdampak positif bagi upaya penciptaan keteraturan kosmik,

Segaran Kecamatan Dlanggu Kabupaten Mojokerto)," Kajian Moral dan Kewarganegaraan 2, no. 1 (2013): 383.

12 Firdaus M. Yunus, "Konflik Agama di Indonesia Problem dan Solusi Pemecahannya," Jurnal Substantia 16, no. 2 (2014): 213. 
sebagaimana Tuhan menghendaki keragaman (pluralitas) itu sebagai sunnatullah.Permasalahannya adalah bahwa tidak semua komunitas umat beragama memiliki kesadaran untuk mengambil dan mengembangkan sisi positif-konstruktif dari keragaman tersebut.

Sebagian kelompok menganggap kelompok lain yang berbeda sebagai musuh yang harus dihindari dan dinafikan eksistensinya. Tetapi juga terdapat komunitas yang menganggap kelompok lain sebagai patner dan memiliki eksistensi yang harus dihargai sebagaimana ia menghargai diri dan agamanya. Hal ini, karena menurut kelompok yang disebut terakhir, beragama (hifdz al-din) merupakan salah satu dari lima hak dasar kemanusiaan (aldharuriyat al-khamsat) yang harus dijunjung tinggi oleh setiap orang. ${ }^{13}$

Pluralisme yang memandang bahwa hakikat yang ada adalah banyak, muncul sebagai respon monisme, karena ukuran kebenaran yang mengandalkan logika semata, tidak mampu memberikan jawaban terhadap kriteria kebenaran yang lain. Situasi ketidakadilan, kesewenangan dan keterasingan psikologis karena hegemoni kapitalisme, juga memicu munculnya pluralisme agama, di samping berbagai peristiwa konflik. Dalam kontek Islam, pluralisme tidak hanya dipandang sebagai realitas sosiologis tetapi juga sebagai fakta teologis sebagai sunnatullah, sebagaimana yang tertera dalam QS.alBaqarah: 62 dan QS. Al-Maidah: 48.

\footnotetext{
${ }^{13}$ Sumbulah dan Nurjanah, Pluralisme agama, 4.
}

Dalam penelitian yang dilakukan Umi Sumbulah dan Nurjanah, dalam Pluralisme Agama Makna dan Lokalitas Pola Kerukunan Antar Umat Beragama memaparkanbahwapluralisme memiliki beberapa makna dalam kerukunan umat beragama, yaitu:

\section{Pluralisme bermakna kerukunan}

Pada poin ini, pluralisme dapat dipahami dengan kebersamaan dan kerukunan antarumat beragama dilaksanakan atas ajaran agamanya dan mengedepankan model kerjasama social kemanuasiaan. Dapat tergambar kerukunan dalam bidang sosial kemasyarakatan dan kemanusiaan, seperti kerjasama untuk membangun bangsa dan negara demi terwujudnya masyarakat yang adil dan makmur, kerjasama dalam bidang pendidikan, kesehatan, perbaikan lingkungan, dan lain sebagainya. Kerjasama antarumat beragama yang terbentuk tidak mengarah pada hal-hal yang bersifat teologis.

\section{Pluralisme bermakna pengakuan atas eksistensi agama lain}

Dalam kehidupan beragama harus mengakui, bahwa agama lain juga bisa eksis dalam segala bidang. Adanya realitas perbedaan-perbedaan syari'at, menunjukkan bahwa agama tidaklah sama. Setiap agama memiliki konteks partikularitasnya sendiri-sendiri, yang tentu berbeda satu dengan lainnya, sehingga tidak mungkin semua agama menjadi simetris, sebangun dan sama persis.

Gagasan pluralisme sesungguhnya menghendaki bahwa setiap umat 
beragama, di samping meyakini agamanya sendiri, juga diharuskan memberikan pengakuan secara aktif terhadap agama lain.

\section{Pluralisme bermakna toleransi}

Pluralisme yang bermakna diatas yakni sebuah sikap harus menghormati agama dan keyakinan orang lain. Ketika komunitas non-muslim melaksanakan ritualnya, maka sebagai orang muslim harus menghargai, karena sikap seperti ini merupakan salah satu sikap dasar bagi prasyarat hidup berdampingan secara damai dan rukun. Adanya toleransi antarumat beragama merupakan salah satu cara meminimalisir potensi konflik antar agama. Potensi destruktif agama dapat mengemuka jika masing-masing komunitas umat beragama tidak menjunjung nilai toleransi dan kerukunan, dengan menganggap agamanya paling benar, superior dan memandang inferior agama lain. ${ }^{14}$

Dalam teologi/doktrin ketuhanan yang berbeda-beda, ada kemungkinan saling bertentangan sehingga memerlukan penghormatan dan penghargaan. Penganut agama yang satu harus menghormati dan tidak boleh mencampuri urusan mengenai keyakinan teologis penganut agama yang lain, demikian pula sebaliknya. Dengan demikian dalam konteks kehidupan beragama, ada domain keyakinan yang harus dibatasi dan dijaga serta saling dihormati, dan ada pula ranah hubungan

\footnotetext{
${ }^{14}$ Alwi Shihab, Islam inklusif: Menuju sikap terbuka dalam beragama (Bandung: Diterbitkan Atas Kerja Sama an Teve Dan Penerbit Mizan, 1997), 41.
}

sosial kemasyarakatan, ekonomi dan politik yang justru harus dijalin dan bekerjasama. Pada wilayah ini, pada gilirannya dapat melahirkan bentukbentuk kerjasama antar penganut agama yang berbeda-beda, yang dalam perjalanan sejarahnya melahirkan harmoni kehidupan bersama dalam wujud budaya, atau yang lebih aplikatif berbentuk kearifan lokal. ${ }^{15}$

\section{Pluralisme bermakna memahami keyakinan hakiki agama lain}

Semua agama memiliki harkat dan martabat masing-masing, sehingga semua komunitas umat beragama diharuskan memahami hal tersebut. Pemahaman terhadap esensi ajaran agama lain ini menjadi relevan dan sangat bermakna, untuk membangun dan menciptakan toleransi serta kerukunan umat beragama yang mengacu pada ajaran yang bersifat kemanusiaan, kasih sayang, persaudaraan dan penghargaan terhadap hak-hak dasar manusia.

Sikap yang seyogyanya dimiliki dan dilakukan setiap orang adalah dengan memahami dan menilai "yang lain" (the other)/ penganut agama lain berdasarkan standar mereka sendiri, serta member peluang bagi mereka untuk mengartikulasikan keyakinannya secara bebas. Dengan demikian pluralisme dalam agama merupakan suatu sikap bahwa tiap pemeluk agama dituntut bukan hanya mengakui keberadaan dan hak orang lain, tetapi juga terlibat dalam usaha

\footnotetext{
${ }^{15}$ Haidlor Ali Ahmad, "Kerjasama Antar Umat Beragama dalam Wujud Kearifan Lokal di Kabupaten Poso," Jurnal Multikultural \& Multireligius VIII (2009): 162.
} 
memahami perbedaan dan persamaan, guna tercapainya kerukunan dalam kebhinekaan.

\section{Pluralisme bermakna kasih sayang}

Secara manusiawi, semua komunitas umat beragama diharuskan saling mengasihi sesama tanpa melihat perbedaan yang ada, seperti mencintai orang lain sebagaimana mencintai diri sendiri. Bahkan Yesus Kristus mengajarkan kepada umat kristiani untuk mencintai musuh-musuhnya. "Cintailah sesama manusia seperti kamu mencintai dirimu sendiri, lakukanlah terhadap orang lain, apa yang ingin kamu lakukan orang terhadap dirimu sendiri". 16

Cinta Tuhan tidak pilih kasih, karenanya manusia sebaiknya meniru sifat Tuhan, ibarat matahari yang tidak pilih kasih, dalam memancarkan cahayanya. Dalam al-Qur'an juga dijelaskan bahwa Allah juga mempunyai sifat Rahman dan Rahim, dengan kasih dan sayangnya sepanjang waktu, tanpa memandang siapa saja, Allah member rizki kepada semua makhluk hidup, alam semesta beserta isinya. ${ }^{17}$

\section{Pluralisme bermakna tujuan semua agama sama}

Agama mengajarkan kebaikan, yang merupakan salah satu tujuan semua agama, hanya saja diantara agama-agama tersebut memiliki perbedaan "jalan" maupun cara dalam praktik ritual. Hal itu tidaklah menjadi sebab ditolak atau

\footnotetext{
${ }^{16}$ Komaruddin Hidayat dan Ahmad Gaus Af, Passing Over: Melintasi Batas Agama (Jakarta: Gramedia Pustaka Utama, 1998), 382.
}

tercelanya seseorang melakukan penghormatan total kepada apa yang diyakininya. Perbedaan jalan dan cara merupakan kekayaan "bahasa" Tuhan yang tidak bisa secara pasti dipahami dan ditangkap maknanya oleh bahasa-bahasa manusia. Memperhatikan hal ini, maka tidak perlu lagi mempersoalkan mengapa antara orang Islam, Kristen, Budha, Hindu dan yang lain tampak berbeda-beda dalam perihal cara menggapai dan mencapai Tuhan.

Perbedaan ritual hanyalah perbedaan lahiriah yang bisa ditangkap oleh kasat mata, sedangkan hakikat ritual adalah"penghormatan" atas apa yang dianggap suci, luhur, agung, dan sebagainya. Perbedaan yang dimiliki oleh masing-masing agama pada dasarnya bersifat instrumental. Sementara dibalik perbedaan itu terkandung pesan dasar yang sama, yakni ketuhanan dan kemanusiaan, yang memungkinkan masing-masing agama dapat melakukan perjumpaan sejati.

\section{Simbol-Simbol Interaksi Sosial Pluralisme Integratif Di Kelurahan Karang Slogihimo Wonogiri}

Simbol-simbol yang dimaksud dalam pembahasan ini adalah berbagai simbol yang digunakan dalam interaksi sosial di Kelurahan Karang Slogohimo Wonogiri. Simbol berasal dari bahasa Yunani symboion dari syimballo yang berarti menarik sesimpulan atau memberi kesan, simbol merupakan salah media

\footnotetext{
${ }^{17}$ Christian Wedemeyer dan Wendy Doniger, Hermeneutics, Politics, and the History of Religions: The Contested Legacies of Joachim Wach and Mircea Eliade (Oxford University Press, 2010), 31.
} 
utuk membuat atau menyampaikan pesan dalam sebuah interaksi sosial. ${ }^{18}$ Dalam interaksi sosial masyarakat tentu tidak bisa lepas dari berbagai simbol-simbol sebagai sarana untuk menyampaikan suatu pesan, dari beragam simbol-simbol yang dimunculkan akhirnya menghasilkan sebuah kebudayaan. Persepektif Interaksionisme Simbolik simbol merupakan sifat khas yang digunakan interaksi antar manusia. Sifat khasnya adalah bahwa manusia saling mendefinisikan dan menterjemahkan tindakannya, bukan sekedar reaksi belaka dari adanya sebuah simbol yang diciptakan oleh orang lain. Tanggapan seseorang atas sebuah simbol tidak dibuat secara langsung tetapi didasarkan atas "makna" yang diberikan terhadap sebuah simbol yang diberikan oleh orang lain. Interaksi antar individu didahului oleh penggunaan simbol-simbol akhirnya menimbulkan sebuah interpretasi atau dengan saling memahami maksud dari tindakan masing-masing. ${ }^{19}$

Dalam Persepektif G.H Mead menyebutkan bahwa interaksi sosial manusia memiliki karakteristik khusus yaitu berinteraksi dengan symbol-simbol yang bermakna dan tidak hanya terbatas pada isyarat-isyarat fisik. Menurutnya perilaku atau tanggapan seseorang sangat dipengaruhi oleh simbol yang diberikan oleh orang lain, demikian pula perilaku orang sebaliknya. Dengan perantara simbol seseorang dapat mengutarakan perasaan, pikiran, maksud dan begitu sebaliknya dengan cara membaca simbol

\footnotetext{
${ }^{18}$ Soerjono Soekanto, Sosiologi Suatu Pengantar, Edisi Baru (Jakarta: Raja Grafindo Persada, 2001), 187.
}

yang diberikan oleh orang lain. Simbol yang dimaksud oleh G.H Mead dalam interaksi sosial bukan saja melibatkan simbol-simbol verbal seperti kata, frase, atau kalimat tetapi juga melibatkan simbol-simbol yang berbentuk non verbal seperti isyarat, ekspresi wajah, kontak mata, bahasa tubuh, dan sebagainya sampai akhirnya membentuk suatu simbol yang mempunyai arti yang sangat penting. Dari berbagai simbol tersebut akhirnya terdapat simbol yang signifikan, kumpulan dari kata, frase, dan kalimat (bahasa) merupakan simbol yang signifikan akhirnya menjadikan manusia berfikir sebelum melakukan sebuah respon atau tanggapan terhadap sebuah simbol yang muncul dalam interaksi sosial.

Demikian juga yang berlangsung di Kelurahan Karang Slogohimo Wonogiri, dalam interaksi sosial mereka menggunakan simbol-simbol. Secara umum sebagaimana pemikiran G.H Mead simbol interaksi sosial yang berlangsung di Kelurahan Karang dikatagorikan menjadi dua yaitu simbol verbal dan non verbal.

\section{Simbol Verbal Interaksi Sosial Masyarakat Karang}

Manusia adalah mahluk sosial (zoon politicon) yang selalu berinteraksi satu sama lain, baik itu dengan sesama, adat istiadat, norma, pengetahuan ataupun budaya yang ada disekitarnya. Setiap manusia sangat membutuhkan itu semua, karena manusia tentu tidak dapat

\footnotetext{
${ }^{19}$ George Ritzer, Sosiologi Ilmu Pengetahuan Berparadigma Ganda, Diterjemahkan Oleh Alimandan (Jakarta: CV Rajawali, 1985), 60-61.
} 
hidup secara individu, dalam praktik kehidupan pasti membutuhkan orang lain. Dan unutk mewujudkan itu semua diperlukan komunikasi yang baik.

Tentu tidak asing bagi kita sebagai warga negara Indoneia dengan adanya perbedaan budaya yang heterogen dikalangan masyarakat, karena mengingat cukup luasnya wilayah Indonesia yang terdiri dan terpisahkan oleh berbagai kepulauan. Hal ini patut membuat bangga sebagai masyarakat kepulauan yang mempunyai kekayaan kebudayaan yang beragam. Akan tetapi, pada kenyataannya seringkali kita tidak bisa menerima atau merasakan kesulitan menyesuaikan diri dengan perbedaan-perbedaan yang terjadi akibat interaksi tersebut. Seperti halnya masalah beda kesukuan, etnis, kebiasaan yang berbeda dari seseorang teman/tetangga atau lebih khusus mengenai bahasa/ komunikasi/ dialek yang mempunyai makna yang hanya bisa direspon oleh hati dan alam perasaan.

Dalam konteks simbol verbal berupa kata, frase, dan kalimat atau bahasa. Masyarakat kelurahan Karang menggunakan simbol verbal dalam kehidupan sehari-hari mnggunakan bahasa Jawa. Adakalanya menggunakan bahasa jawa ngoko, kromo alus, dan kromo inggil tergantung dimana dan dengan siapa mereka berinteraksi. Khusus untuk bahasa Indonesia biasanya digunakan dalam pertemuan-pertemuan resmi di tingkat Kelurahan. Filosofi "gupuh, aruh, suguh" masih begitu kental dan melekat dalam kehidupan sehari-hari di Karang,

\footnotetext{
${ }^{20}$ M. Shohibul Itmam, "Analisis Interaksionisme Simbolik Masyarakat Beda Agama Di Kelurahan Karang, Kecamatan Slogohimo, Kabupaten
}

hal ini dapat kami rasakan ketika beberapa kali kami datang disana hampir selalu mendapatkan sambutan dan respon yang hangat dari semua lapisan masyarakat yang berada di kelurahan Karang Slogohimo. Gupuh kurang lebih memiliki makna sesegera mungkin tuan rumah menyambut tamu dengan ramah dengan khas bahasa keseharian mereka "monggo pinarak" sebagai sebuah respon dari "kulo nuwun" atau assalamu'alikum dalam kebiasaan umat Islam. Aruh makna bebasnya adalah menyapa kepada siapapun ketika bertemu atau bertamu dengan sopan dan ramah, dan terakhir suguh memiliki makna memberikan sebagian rezeki (makanan, minuman, atau hidangan lain yang mereka miliki) dengan suka rela tanpa sebuah paksaan bahkan diyakini sebagai budaya seperti filosofinya "wedang sak gelas kanggo nyambung paseduluran" air minum satu gelas sebagai bentuk atau sarana untuk menyambung tali persaudaraan. Yang menjadi menarik simbol filosofi "gupuh, aruh, suguh" ini mereka perlakukan kepada semua orang yang berada diwilayah tersebut maupun pendatang dengan tanpa membedakan suku, ras, golongan, maupun agamanya.

\section{Simbol Non Verbal Interaksi Sosial Masyarakat Karang, Slogohimo, Wonogiri. ${ }^{20}$}

Sebagaimana disampaikan oleh Mead bahwa dalam suatu interaksi sosial selain melibatkan simbol-simbol verbal, juga melibatkan proses pertukaran simbol yang bersifat non verbal seperti syarat,

Wonogiri," Dalam Penelitian Unggulan Bidang Humaniora/Sosiokultural. Lembaga Penelitian dan Pengabdian Masyarakat (LPPM), 2017. 
ekspresi wajah, kontak mata, dan sentuhan sampai akhirnya membentuk satu bentuk simbol yang mempunyai arti yang sangat penting. Sebagaimana yang dimaksud dalam teori Interaksionisme Simbolik, simbol-simbol non verbal juga banyak ditemukan di Masyarakat Karang Slogohimo Wonogiri. Mengangukkan kepala misalnya sebagai bentuk simbol sebagai isyarat bahwa seseorang yang berinteraksi dapat memahami pola komunikasi yang mereka bangun dalam berkomunikasi walaupun lintas agama, ekspresi wajah misalnya dalam berbagai kesempatan yang memungkinkan berbagai masyarakat yang berbeda agama tersebut dapat bertemu misalnya di kantor balai desa, di sawah, di sekolah, dan dimana saja mereka juga menunjukkan ekspresi wajah yang sopan (tidak cemberut, penuh curiga, atau menunjukkan tanda-tanda kekesalan), begitu juga dengan kontak mata maupun sentuhan yang sering kali mereka lakukan dalam interaksi lintas agama dengan menghadiri berbagai kegiatan-kegiatan sosial masyarakat.

Sehingga dari berbagai pertukaran simbol-simbol yang seringkali mereka lakukan dalam proses interaksi sosial tersebut akhirnya mereka secara bersama-sama menciptakan sebuah simbol-simbol dalam interaksi antar umat beragama yang dijadikan sarana untuk pemersatu dari berbagai keragaman agama yang ada di Karang Slogohimo. Selain faktor turun-temurun yang telah mereka lestarikan dari ajaran para luhur mereka serta ditambah pertukaran sibombol-simbol yang mereka adaptasi maupun modifikasi sesuai perkembangan zaman di era global.

Dari berbagai bentuk pertukaran symbol-simbol tersebut akhirnya menimbulkan kesepakatan bersama dan di dalamnya melebur budaya atau tradisi serta komunikasi yang terbentuk pun antara verbal dan non verbal seringkali digunakan secara bersamaan. Berbagai bentuk simbol yang mereka klaim sebagai sarana untuk bersatu dalam kebhinekaan atau pluralisme integrative di kelurahan Karang Slogohimo Wonogiri dalam bentuk simbol-simbol non verbal adalah sebagai berikut;

\section{a. Gotong Rotong}

Ditengah arus globalisasi seperti era sekarang ini berbagai simbol budaya asli Indonesia utamanya masyarakat jawa banyak simbol-simbol yang tergerus oleh arus globalisasi semisal simbol pakaian, gaya bicara, intensitas berkomunikasi dan lain sebagainya salah satu yang patut dilestarikan namun banyak yang hilang di beberapa daerah khususnya area perkotaan adalah budaya gotong royong. Sebagai kelurahan yang masyarakatnya terdiri dari beragam agama maka gotong royong di Karang masih dilaksanakan secara intensif sebagai salah satu simbol untuk menjaga kerukunan antar warga maupun antar umat beragama. Mulai dari tingkat RT, RW maupun Kelurahan masing masing dusun di kelurahan Karang mempunyai program gotong royong dengan melibatkan seluruh elemen yang ada dalam masyarakat tersebut mulai dari tokoh pemerintahan, tokoh agama, warga, remaja tanpa memandang suku, ras maupun agama semua bahu membahu 
membaur secara bersamaan dengan penuh semagat gotong royong. Diantara bentuk-bentuk gotong royong yang melibatkan masyarakat lintas agama di kelurahan Karang Slogohimo baik dalam bidang agama, ekonomi, sosial, pendidikan dan lain sebagainya.

\section{Memperbaiki Jalan}

Mulai dari jalan di tingkat Rt, Rw, Dusun sampai Kelurahan semua ada agenda gotong royong ada yang mingguan, bulanan, atau kondisional. Teknik pelaksanaan dari sistem gotong royong ini adalah dipantau langsung oleh Rt, Rw atau Kadus dari masing-masing wilayah dusun dengan masing-masing dari kepala keluarga mengirimkan perwakilan untuk mengikuti kegiatan kerja bakti. Bisa lakilaki, perempuan atau remaja tergantung tingkat kesulitan gotong royong yang dikerjakan. Konsekwensi dari mereka yang tidak hadir atau tidak mengirim anggota keluarganya dalam kegiatan kerja bakti ini, selain sangsi sosial dari masyarakat sekitar mereka juga di kenakan denda dalam bentuk uang atau barang tergantung kesepakatan dari masing-masing wilayah atau dusun di kelurahan tersebut.

\section{Membangun Tempat Ibadah}

Membangun tempat ibadah (Masjid, Gereja, Wihara atau pun Padepokan) di kelurahan ini walaupun dalam praktek ibadah yang menempati tempat ibadah adalah mereka yang sesuai dengan keyakinannya. Namun dalam hal pelaksanaan membangun tempat ibadah justru seluruh warga masyarakat terlibat secara sukarela tanpa diundang, hanya dari mendengar atau kabar dari mulut ke mulut mereka dari berbagai latar belakang agama yang berbeda-beda bahu membahu membantu proses pembangunan tempat ibadah dari setiap masing-masing pemeluk agama tersebut tanpa memandang siapa dan agama apa tempat ibadah yang hendak dibangun.

Dalam proses gotong royong membangun tempat ibadah tersebut terdapat beberapa simbol verbal maupun non verbal sebagai sarana untuk menjadikan pluralisme yang integratif. Misal simbol "wedangan" yaitu kebiasaan dipagi hari sebelum mereka bekerja dengan suasana keakraban minum teh sambil memakan makanan ringan dengan pembicaraan-pembicaran ringan namun terselib beberapa percakapan semisal bertanya kabar, apabila ada salah satu agama baru saja punya kegiatan bagi mereka yang tidak datang bertanya bagaimana kegiatannya, atau berbagai kegiatan positif lain dengan saling tukar menukar informasi. Setelah itu mereka bergotong royong bersamasama tanpa mengenal strata sosial dan biasanya berakhir dengan makan siang dengan suasana yang penuh dengan keakraban.

\section{Gotong Royong dalam Pernikahan}

Kebiasaan suatu rangkaian pernikahan di Kelurahan Karang berlangsung selama kurang lebih tiga hari tiga malam yang digelar secara berturutturut.Dari berbagai rangkaian kegiatan tersebut melibatkan berbagai unsur masyarakat yang ada di sekitarnya mulai dari awal kegiatan sampai akhir. Misalnya untuk para tokoh lintas agama terlibat dalam kegiatan among tamu, para remaja terlibat dalam kegiatan pramusaji atau 
dalam istilah Karang disebut dengan "Pladen", warga sekitar baik laki-laki maupun perempuan terlibat dalam urusan dapur yang penting "dijawil" atau diberitahu siapa pun yang punya hajat pasti dibantu dengan baik oleh seluruh warga sekitar tanpa memandang latar belakang agamanya.

Belum lagi ada istilah "grubyukan" atau besanan, baik menerima besan atau bertandang secara bersama-sama kerumah besan. Dengan melibatkan warga sekitar kebiasaan grubyukan ini adalah sebagai sarana untuk menyatukan dari berbagai ragam latar belakang agama yang berbeda-beda. Selain karena sudah menjadi sebuah tradisi maka bagi mereka yang membeda-bedakan justru akan mendapatkan dampak sosial ditengahtengah masyarakat menjadikan dirinya asing ditengah tengah keberagaman yang ada.

\section{Peringatan Hari Kemerdekaan RI}

Istilah perayaan hari kemerdekaan ini di Karang disebut dengan istilah "agustusan".Dalam perayaan agustusan banyak sekali beragam kegiatan yang mempertemukan seluruh lapisan masyarakat untuk membuat sebuah konsep perayaan agustusan yang dapat diikuti oleh seluruh warga masyarakat Karang secara meriah tanpa mempersoalkan dari latar belakang agama ataupun keyakinan.

Beragam kegiatan dilaksanakan secara kompak dengan semangat gotong royong mulai dari warga biasa sampai perangkat desa. Beberapa contoh kegiatannya adalah memasang bendera umbul-umbul yang dipasang disetiap sudut jalan dikelurahan
Karang khas dengan pernak pernik lampu hiasnya, berbagai lomba khas agustusan semisal sepak bola antar dusun, Bola Voli, Karnaval, Panjat Pinang, Lomba anak-anak dan berbagai lomba-lomba tradisional masih intens dilakukan oleh warga masyarakat Karang. Walaupun tidak dapat dipungkiri bahwa terkadang terjadi kontestasi dari aksi saling mendukung maupun memberi suport kepada warga yang mungkin kebetulan satu agama, atau satu RT itu semua hanya dalam rangka memotivasi dan memeriahkan lomba águstusan yang sedang berlangsung.

\section{b. Arisan Lintas Agama}

Kegiatan arisan ini sangat beragam di kelurahan Karang tetapi hampir disetiap RT, Rw atau Dusun dipastikan ada kelompok arisan. Mulai dari arisan pemuda, arisan ibu-ibu, ataupun arisan bapak-bapak yang menarik jika di berbagai daerah yang lain arisan ini biasanya ada kegiatan-kegiatan kegamaan, tetapi di kelurahan Karang justru membahas tentang kegiatan yang bisa memajukan pergerakan desa "kalau pemuda/remaja biasanya membahas persoalan karang taruna, kalau arisan bapak - bapak/ibu-ibu tema arisan membahas tentang koperasi bersama, ataupun informasi-informasi mengenai lingkungan dan kegiatan gotongroyong yang berlangsung. Sedangkan forumforum keagamaan meraka bahas secara tersendiri di tempat Ibadah masingmasing atau acara-acara khusus yang berhubungan dengan kegiatan keagamaan. 


\section{c. Bersih Desa}

Bersih desa merupakan salah satu tradisi yang dilestarikan di Karang Slogohimo. Sedang waktu pelaksanaan bersih desa satu tahun sekali biasanya sesudah musim panen padi. Terkait soal tanggal, bulan, tempat dan waktu pelaksanaannya tidak selalu sama dari masing-masing tahun biasanya ada musyawarah yang diprakarsai oleh sesepuh desa. Rangkaian upacara bersih desa biasanya didahului oleh kegiatan bersih-bersih desa dari segala kotoran, selokan, pagar dan lain sebagainya sehingga kampong dalam kelihatan bersih, indah dan dalam suasana yang menyenangkan. Termasuk membersihkan makam yang dilaksanakan secara bersama-sama oleh seluruh warga sekitar dusun. Jika memungkinkan untuk mengundang kesenian tertentu biasanya dipuncak kegiatan dilakukan kegiatan hiburan dengan mengundang wayang kulit, atau campursari.

Salah satu tujuan dari dilaksanakannya bersih desa di Kelurahan tersebut adalah untuk melestarikan budaya jawa dan menjaga hubungan yang harmonis antara Tuhan, Alam dan Sesama manusia. Tujuan diadakannya membawa nasi atau tumpeng yang dibawa ketika malam puncak dan bersamaan dengan kegiatan kesenian merupakan sebagai ungkapan rasa syukur kepada Tuhan atas hasil panen yang didapatkan, sebagai ajang silaturahmi antar warga, dan hiburan bagi warga dan juga terkadang dijadikan sarana informasi dari pejabat kelurahan untuk menyampaikan sebuah informasi kepada warga. Dalam budaya bersih desa semua warga di Kelurahan
Karang terlibat dalam kegiatan tersebut dari berbagai latar belakang agama yang berbeda-beda. Semua bekerja sesuai dengan tugas pokok dan fungsi sebagaimana hasil kesepakatan pada saat musyawarah dengan para tokoh dan sesepuh desa.

\section{d. Megengan}

Megengan adalah simbol tradisi yang dilakukan oleh warga masyarakat sebagai pertanda bahwa sebentar lagi memasuki bulan ramadhan atau mereka mengistilahkan dengan istilah "poso". Tradisi yang ditandai dengan kenduri atau kondangan selamatan ini biasanya dilakukan dari satu rumah kerumah yang lain secara bergantian, di kelurahan Karang biasa juga disebut dengan acara "mapak tanggal" untuk menyongsong datangnya bulan suci ramadhan.

$$
\text { Kalau dibeberapa daerah }
$$
megengan ini yang melaksanakan umat Islam yang masih melestarikan budaya lokal, lain halnya di kelurahan Karang Slogohimo kendati bulan suci Ramadhan pasti identik dengan umat Islam akan tetapi yang melaksanakan megengan ini bukan saja umat Islam namun dari berbagai agama yang ada disana mulai dari Budha, Kristen, Protentan, dan Islam unik nya lagi mereka juga tidak hanya sekedar ikut dan datang tetapi mereka juga bagian dari yang menyiapkan ritual megengan tersebut di rumah masingmasing. Bersamaan dengan ritual megengan biasanya diadakan gotong royong membersihkan makam atau kuburan yang diikuti dengan ziarah makam leluhur. 


\section{e. Ruwatan Desa}

Ruwatan merupan salah satu simbol upacara tradisional yang sampai saat ini masih dilestarikan. Kegiatan ini dilestarikan mengingat keberadaannya memang dianggap masih memiliki banyak manfaat bagi warga. Sebagaimana disebutkan oleh salah satu warga dari tokoh agama budha bahwa ruwatan pada mulanya berkembang dalam sebuah cerita jawa kuno yang pada pokoknya memuat masalah penyucian, ruwatan juga sering diartikan sebagai upaya untuk mengatasi atau menghindari sesuatu kesulitan yang mungkin akan diterima seseorang dalam mengarungi kehidupan lebih-lebih dalam hal pekerjaan. Untuk menyelenggarakan ruwatan ini kalau dalam lingkup keluarga ada aturan-aturan tersendiri yang beraneka ragam, namun kalau dalam lingkup kelurahan dilaksakan minimal satu tahun sekali walaupun terkadang pelaksanaannya bersamaan dengan acara bersih desa, bergabung atau tidaknya disesuaikan dengan keinginan warga dan kas dusun atau kelurahan yang didapatkan dari iuran antar warga yang dikumpulkan secara berkala.

Selain itu dalam ruwatan biasanya diselenggarakan wayang kulit ini sematamata untuk melestarikan budaya jawa dan memberikan hiburan kepada warga kelurahan Karang.

\section{f. Ngemit Jenazah}

Apabila ada seorang warga yang meninggal pada waktu sore hari kebiasaan di kelurahan ini, maka pemakamnnya tidak langsung pada waktu malam harinya, tetapi menunggu sampai keesokan harinya sampai menjelang siang atau tergantung keluarga jenazah karena bisa sampai sore dengan alasan menunggu datangnya sanak saudara yang kebetulan berada di luar kota. Ngemit ini merupakan rangkaian kegiatan sebelum prosesi layatan (takziah) dilaksanakan, yaitu pada waktu malam hari seluruh warga sekitar dengan tanpa membeda-bedakan agama mereka berkumpul sampai malam bahka sampai pagi sebagai bentuk dari ungkapan turud berduka cita sambil menyiapkan segala hal yang berhubungan dengan kegiatan layatan dan prosesi pemakaman jenazah.

\section{g. Kenduri / Selametan}

Kenduri atau slametan merupakan perwujudun rasa syukur terhadap nikmat yang telah diberikan oleh Tuhan Yang Maha Esa, dan atau prosesi mengharap keselamatan atau kelancaran suatu hal, dengan sarana do'a sebagai medianya. Akan tetapi ada satu titik temu bahwa kenduri/kenduren/slametan menurut kepercayaan warga merupakan ungkapan wujud rasa syukur kepada sang pencipta atas segala nikmat yang diberikan dan sebagai sarana berdo'a untuk kelancaran setiap kegiatan pada masa yang akan datang.

Ada beberapa kenduren yang biasanya dilakukan oleh warga kelurahan Karang misalnya kenduren wetonan (hari lahir), kenduren ketika ada beberapa peristiwa semisal kelahiran anak, hewan ternaknya bertambah, dapat membeli motor atau mobil baru, kenduren likuran yaitu kenduren yang dilaksanakan pada malammalam ganjil pada bulan ramadhan, dan sebagainya. Begitulah kiranya sebagaimana tradisi-tradisi yang lain yang 
dilestarikan oleh semua warga di kelurahan Karang dengan tanpa memandang unsur agama mereka meyakini bahwa kenduren merupakan sebagai salah satu sarana yang efektif untuk mempererat tali persaudaraan dan persatuan antar warga yang berbeda-beda agama dan keyakinannya.

\section{h. Methik Menjelang Panen Padi}

Simbol "methik" merupakan salah satu tradisi masyarakat kelurahan Karang yaitu ritual yang dilaksanakan sebelum memanen padi. Proses ini dimaksudkan untuk menjemput dewi padi yang dikenal dengan sebutan dewi sri. Kendati tradisi turun temurun dari warisan leluhur ini sudah jarang yang melakukan dengan berbagai argumennya, namun masyarakat Karang tetap melaksanakan karena tradisi methik ini merupakan simbol rasa syukur kepada sang pencipta atas berkah dan karunia yang dilimpahkan serta ungkapan simbol kepada dewi sri sebagai ungkapan kemakmuran. Selain itu ritual methik juga memiliki simbol persatuan yaitu dengan mengundang warga masyarakat sekitar dari berbagai latar belakang agama untuk datang di sawah dan menjadi persaksian atas ucapan rasa syukur terhadap berbagai rezeki yang melimpah, setelah itu makan bersama sebagai pertanda akan dimulainya panen raya dan dilanjutkan dengan memetik padhi secara bersamasama secara bergantian atau kalau sibuk biasanya dipekerjakan kepada orangorang sekitar yang hendak bekerja.

\section{i. Fitrahan dan Ngider}

Mendengar istilah fitrahan, spintas yang terlintas adalah membayar zakat fitrah sebagaimana pada umumnya, namun istilah fitrahan disini digunakan pada tradisi berkumpul secara bersamasama lengkap dengan seluruh anggota keluarganya pada hari kedua hari raya idul fitri yang bertempat dirumah kepala dusun atau tokoh yang dianggap sesepuh desa. Acara ini hampir mirip dengan acara halal bihalal, hanya saja kalau acara fitrahan diprakarsai oleh kepala dusun atau sesepuh desa yang dianggap memiliki pengaruh, baik konsep acara maupun jamuannya, disebut fitrahan karena setelah acara tersebut selesai dilanjutkan dengan acara saling berjabat tanggan kemudian kepala dusun atau sesepuh desa memberikan "sangu" atau "ampau" kepada semua anak-anak kecil yang datang dalam acara tersebut.

Setelah acara ini selesai walaupun mereka hampir semuanya bertemu akan tetapi masih disambung dengan acara "ngider" bertandang dari rumah warga yang satu kerumah warga yang lain secara bersama-sama dan bergantian. Simbol tradisi ini tidak saja dilaksanakan oleh mereka yang beragama Islam, namun semua warga desa apapun agamanya secara bersama-sama mengikutinya baik tradisi fitrahan ataupun ngider. Nilai yang dapat diamabil tradisi tersebut bukan berarti mencampuradukkan sebuah keyakinan agama mereka menyebutkan lebih pada penekanan simbol tradisi dan toleransi dalam menjaga harmonisasi dari keberagaman yang ada.Mereka menambahkan yang penting tidak ikut campur atau ikut-ikutan dalam peribadahan antar masing-masing agama ketika berada di tempat ibadah maka 
bukan berarti mencampuradukkan keyakinan dalam beragama.

\section{Penutup}

Bentuk simbol interaksi social dalam mengenal pluralisme disintegrative menuju pluralisme Integratif masyarakat beda agama Kelurahan Karang Slogohimo Wonogiri ini, secara umum simbol-simbol tersebut dikatagorikan menjadi dua bentuk yaitu simbol verbal dan simbol non verbal. Simbol verbal berupa kata, frase atau kalimat maupun bahasa dalam hal ini berupa slogan-slogan jawa yang mereka yakini dapat membangkitkan semangat kebersamaan dalam keberagaman yang plural misalnya "gupuh, aruh, suguh, podho kulit lan balunge, rukun makmur, crah anggawe susah" berbagai simbol berupa kata, frase, kalimat ataupun bahasa jawa tersebut sangat kuat untuk dijadikan sebagai sebuah prinsip dalam membangun sebuah interaksi sosial tanpa memandang suku, ras maupun agama. Selain itu, berbagai simbol verbal lain yang mereka gunakan dalam kehidupan sehari-hari yang secara intens mereka gunakan dalam setiap pertemuan baik di sawah, ladang, jalan, maupun dimanapun dan kepada siapapun mereka mencoba untuk selalu bertanya dan bertegur sapa sehingga suasana akrab dan ramah disetiap kesempatan tersebut dapat menjadi sarana untuk membangun keberagaman yang integratif.

Simbol-simbol non verbal berupa berupa isyarat, ekspresi wajah, bahasa tubuh, ataupun simbol lain berupa tradisi atau kebudayaan yang telah mereka lestarikan dari masa ke masa selalu dijadikan sebagai sarana interikasi sosial dari berbagai ragam masyarakat yang berbeda-beda. Isyarat, ekspresi wajah, bahasa tubuh yang mereka tampakkan dalam setiap kali berinteraksi sosial selalu memancarkan aura yang positif tanpa menaruh rasa curiga ataupun prasangka terhadap mereka yang berbeda agama ataupun pendatang sekalipun. Berbagai budaya "gotong royong" membangun jembatan, tempat ibadah, membantu dan menghadiri pesta pernikahan, menjenguk warga yang sakit, peringatan hari besar keagamaan, peringatan hari kemerdekaan) ataupun kegiatan-kegiatan lain yang memerlukan semangat gotong royong masih begitu melekat bagi warga masyarakat kelurahan Karang Sloghohimo Wonogiri baik generasi muda, tua, masyarakat biasa maupun pejabat semua terlibat dan memiliki peraturan yang sama. Selain itu bentuk simbol non verbal lain seperti arisan lintas agama, kegiatan bersih desa, megengan, ruwatan desa, ngemit jenazah, kenduri atau slametan, methik, fitrahan dan ngider merupakan sarana interaksi yang positif antar sesama warga kelurahan Karang Slogohimo Wonogiri tanpa membeda-bedakan latar belakang keyakinan agamanya.

Kesimpulannya adalah dari sumber kekayaan budaya yang ada di negara Indonesia ini sebagai manifestasi rasa syukur kepada kehadirat Tuhan Yang Maha Esa, wujud produk budaya diatas merupakan implementasi dari peran masyarakat bangsa kita yang menganut prinsip sebagai bangsa yang Berbhineka Tunggal Ika. Adapun tugas kita sebgai warga negara yang berperadaban harus bisa melestaraikan warisan budaya tak ternilai harganya ini, menjadikannya 
sebagai sumber investasi kekayaan, yang tidak hanya mendatang sumber pendapatan (sektor pariwisata) akan tetapi kiblat pengetahuan dunia sebagai rujukan dalam menata sebuah masyarakat multi kultural menjadi masyarakat saling menjaga tolerasi. Selain itu, tidak hanya kaya jumlah materi namun sangat melimpah dalam wujud kearifan lokal sebagai wujud kekayaan/warisan pluralisme yang wajib kita junjung tinggi sebagai cipta rasa karsa budaya bangsa kita.

\section{DAFTAR PUSTAKA}

Ahmad, Haidlor Ali. "Kerjasama Antar Umat Beragama dalam Wujud Kearifan Lokal di Kabupaten Poso." Jurnal Multikultural \& Multireligius VIII (2009).

Analisis Interaksionisme Simbolik

Masyarakat Beda Agama

Kelurahan, Karang, Slogohimo,

Wonogiri. Ponorogo: IAIN

Ponorogo, 2017.

Azhari, Muntaha, dan Abdul Mun'im

Saleh. Islam Indonesia menatap

masa depan. Jakarta: Perhimpunan

Pengembangan Pesantren dan

Masyarakat, 1989.

Coward, Harold. Pluralisme dan

Tantangan Agama-Agama.

Yogyakarta: Kanisius, 1989.

Desa, Balai Pemberdayaan Masyarakat.

"Daftar Isian Potensi Desa dan

Kelurahan, lampiran II

Permendagri No. 122007

Pedoman Penyusunan dan

Pendayagunaan Data Profil Desa dan Kelurahan," 2012.

Hidayat, Komaruddin, dan Ahmad Gaus

Af. Passing Over: Melintasi Batas

Agama. Jakarta: Gramedia Pustaka Utama, 1998.
Itmam, M. Shohibul. "Analisis Interaksionisme Simbolik Masyarakat Beda Agama Di Kelurahan Karang, Kecamatan Slogohimo, Kabupaten Wonogiri." Dalam Penelitian Unggulan Bidang Humaniora/Sosiokultural. Lembaga Penelitian dan Pengabdian Masyarakat (LPPM), 2017.

Kusumastuti, Erwin. "Strategi dan Praktik Kerukunan Beragama dalam Perspektif Pendidikan Multikultural." UIN Sunan Kalijaga, 2016.

Nisvilyah, Lely. "Toleransi Antarumat Beragama Dalam Memperkokoh Persatuan Dan Kesatuan Bangsa (Studi Kasus Umat Islam Dan Kristen Dusun Segaran Kecamatan Dlanggu Kabupaten Mojokerto)." Kajian Moral dan Kewarganegaraan 2, no. 1 (2013). Priyono, Priyono. "Pluralisme Agama dan Konflik." Analisa Journal of Social Science and Religion 15, no. 02 (2008): 137-161.

Ritzer, George. Sosiologi Ilmu Pengetahuan Berparadigma Ganda, Diterjemahkan Oleh Alimandan. Jakarta: CV Rajawali, 1985.

Shihab, Alwi. Islam inklusif: Menuju sikap terbuka dalam beragama. Bandung: Diterbitkan Atas Kerja Sama an Teve Dan Penerbit Mizan, 1997.

Soekanto, Soerjono. Sosiologi Suatu Pengantar. Jakarta: Raja Grafindo Persada, 2001.

Sumbulah, Umi, dan Nurjanah Nurjanah. Pluralisme agama: Makna dan lokalitas pola kerukunan antarumat beragama. Malang: UIN Maliki Press, 2013.

Wach, Joachim. The Sociology of Religion. Chicago: University of Chicago Press, 1971. 
Wedemeyer, Christian, dan Wendy Doniger. Hermeneutics, Politics, and the History of Religions: The Contested Legacies of Joachim Wach and Mircea Eliade. Oxford University Press, 2010.

Yunus, Firdaus M. "Konflik Agama di Indonesia Problem dan Solusi Pemecahannya." Jurnal Substantia 16 , no. 2 (2014). 


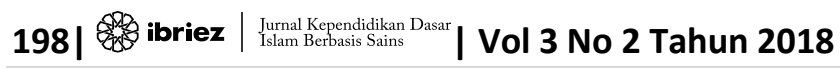

